\title{
Evaluation of bias in HIV seroprevalence estimates from national household surveys
}

\author{
V Mishra, B Barrere, R Hong, S Khan
}

Macro International Inc, Calverton, Maryland, USA

Correspondence to: Dr Vinod Mishra, Demographic and Health Research Division,

Macro International Inc, 11785 Beltsville Drive, Calverton, Maryland 20705, USA; vinod. mishra@macrointernational. com

Accepted 15 May 2008

\author{
ABSTRACT \\ Objectives: To evaluate HIV seroprevalence estimates \\ from demographic and health surveys (DHS) and AIDS \\ indicator surveys (AIS) for potential bias because of non- \\ response and exclusion of non-household population \\ groups.
}

Methods: Data are from 14 DHS/AIS surveys with HIV testing, conducted during 2003-6. Blood samples were collected and analysed for HIV using standard laboratory and quality control procedures. HIV prevalence among non-tested adults was predicted based on multivariate statistical models of HIV for those who were interviewed and tested, using a common set of predictor variables. Estimates of the size of non-household populations in national censuses were used to assess potential bias because of their exclusion in the household surveys under different assumptions about proportion of adults and HIV prevalence in non-household populations.

Results: Non-tested men had significantly higher predicted HIV prevalence than those tested in eight of the 14 countries, while non-tested women had significantly higher predicted prevalence than those tested in seven of the 14 countries. Effects of non-response were somewhat stronger in lower-prevalence countries. The overall effect of non-response on observed national HIV estimates was small and insignificant in all countries. Estimated effects of exclusion of non-household population groups were generally small, even in concentrated epidemics in India and Cambodia under the scenario that $75 \%$ of the nonhousehold population was adults having 20 times greater HIV prevalence than adults in household surveys.

Conclusions: Non-response and the exclusion of nonhousehold population groups tend to have small, insignificant effects on national HIV seroprevalence estimates obtained from household surveys.

In countries with generalised epidemics, national estimates of HIV prevalence levels and trends in the adult population are generally derived indirectly from HIV surveillance among pregnant women attending selected antenatal clinics. ${ }^{12}$ Recently, HIV seroprevalence data have also been collected in national population-based surveys, such as the demographic and health surveys and AIDS indicators surveys. ${ }^{3}$ These surveys have enabled direct estimates of population HIV prevalence. $^{45}$

A major challenge for the surveys is potential bias as a result of non-response. ${ }^{4-8}$ Some eligible respondents may be absent at the time of the survey while others may be incapacitated or refuse to participate. The survey estimates of HIV prevalence may be biased to the extent that nonresponders have different HIV prevalence levels than the responders. There is much evidence that mobility, which is one of the reasons for absence at the time of the survey, tends to be associated higher-risk sexual behaviours ${ }^{9-11}$ and risk of sexually transmitted infections, ${ }^{12}{ }^{13}$ including HIV infection. ${ }^{9-11} 14$ But some studies have failed to find an association between mobility and risk of HIV infection. ${ }^{15}{ }^{16}$ There is limited, inconclusive research on how refusal to participate in population-based surveys is associated with risky sexual behaviours. ${ }^{6}{ }^{17}$ In a recent study that included an assessment of non-response bias in five countries, Mishra et $a l^{4}$ concluded that non-responders tend to have somewhat higher HIV prevalence, but this bias has no significant effects on national seroprevalence estimates. Other previous studies have also failed to establish that population-based surveys significantly downwardly bias national HIV seroprevalence estimates. ${ }^{17-19}$

Another major challenge for the surveys is potential bias because of the exclusion of nonhousehold population groups. Survey estimates may be biased to the extent that people residing in institutions (such as brothels, prisons, hostels, military/police barracks, long-term care homes) or those who are homeless have different HIV prevalence levels than those living in households and included in the survey sample. While there is considerable evidence that some of the institutional populations (such as brothels ${ }^{20}{ }^{21}$ and prisons $^{22}{ }^{23}$ ) and the homeless ${ }^{24}$ tend to have higher risk of HIV infection, there is no previous empirical research to examine how exclusion of non-household population groups might impact national prevalence estimates based on household samples.

In this study, we expand the analysis of nonresponse bias in HIV seroprevalence estimates to 14 demographic and health surveys (DHS) and AIDS indicator surveys (AIS). Additionally, in five surveys with varying levels of HIV prevalence, we evaluate potential bias in national seroprevalence estimates because of exclusion of non-household population groups.

\section{METHODS}

This study uses data from 14 nationally representative surveys of adult women and men, conducted during 2003 and 2006. Eleven of these surveys were DHS: Burkina Faso, Cambodia, Cameroon, Ethiopia, Ghana, India, Kenya, Lesotho, Malawi, Rwanda, Zimbabwe; and three were AIS: Cote d'Ivoire, Tanzania, Uganda. All these surveys included HIV testing and HIV serostatus data were linked to respondents' socioeconomic and behavioural characteristics. Dried blood spot samples were collected (venous blood in Uganda) and analysed for HIV using standard laboratory and 
quality control procedures and internationally accepted ethical standards. ${ }^{25}$ HIV test results were linked anonymously to the characteristics and behaviours of the survey respondents.

In most surveys, nationally representative samples of women age 15-49 and men age 15-59 were tested for HIV. The only exceptions are Uganda where women age 15-59 were tested; Tanzania, Cote d'Ivoire and Cambodia where men age 15-49 were tested, and India, Kenya, Malawi and Zimbabwe where men age 15-54 were tested. In the 14 countries included in this analysis, the numbers eligible for HIV testing ranged from 3305 males (15-59) and 3758 females (15-49) in Lesotho to 64175 males (15-54) and 62182 females (15-49) in India.

\section{Analysis of bias because of non-response}

To estimate the extent of non-response bias and its potential impact on the observed HIV rates in the 14 countries with linked data, all eligible respondents were divided into four groups: (1) interviewed and tested; (2) not interviewed but tested; (3) interviewed, not tested; and (4) not interviewed, not tested. Eligibility for individual interview and HIV testing was based on de facto population.

To evaluate the effect of non-response bias on the survey estimates, HIV prevalence is predicted among non-responding adults (groups 3 and 4 ) based on multivariate models of HIV for those who were interviewed and tested (group 1), using a common set of predictor variables. A logistic regression model is used, after accounting for clustering in the survey design, to calculate predicted HIV prevalence separately for the "not interviewed, not tested" and "interviewed, not tested" groups. Predictions for the "not interviewed, not tested" group are based on a limited set of variables (only from the household questionnaire), but predictions for the "interviewed, not tested" group additionally use several individual sociodemographic and behavioural characteristics of the respondents, as collected in the survey (see footnotes to table 2).

Multivariate analyses used Stata version 9.0. Analysis was carried out separately for males and females for each country. Adjusted HIV prevalence was calculated as a weighted average of observed prevalence among those who were tested and predicted prevalence in the two groups of non-tested respondents. Sampling weights were applied in accordance with standard DHS procedures. We used HIV sampling weights for the tested, individual sampling weights for the "interviewed, not tested", and household sampling weights for the "not interviewed, not tested" groups, respectively.

\section{Analysis of bias because of exclusion of non-household population}

In five of the countries (Cambodia, India, Ghana, Uganda and Lesotho), we examine potential bias because of exclusion of non-household population groups on the survey estimates of HIV prevalence for adults age 15-49. These countries were chosen to represent countries at varying levels of HIV prevalence.

For this purpose, we obtained national estimates of the size of household population, size of non-household population (including both institutional and homeless), total population, the annual population growth rate and the proportion of adults age 15-49 in the total population in each country. ${ }^{26-30}$ Using the annual growth rate, the household, non-household and total population sizes were projected to the DHS survey year. Next, using the proportion of adults in the total population, numbers of adults in the household, non-household and total population were estimated for the survey year. Adults are more likely to live in institutions and be homeless than children or elderly, but information on the age structure of the non-household population was not readily available from census in most cases. We therefore used different assumptions about the proportion of adults in the non-household population and the level of HIV prevalence among non-household adults to estimate overall HIV prevalence among all adults in each country (accounting for exclusion of non-household population groups).

We estimated the potential impact of excluding non-household population groups under the following three scenarios:

- Scenario A (baseline): The proportion of adults (15-49) in the non-household population is the same as in the census population; and HIV prevalence among non-household adults is the same as the prevalence among adults in the household survey.

- Scenario B: The proportion of adults (15-49) in the nonhousehold population is $66.67 \%$; and the HIV prevalence among the non-household adults is 10 times in India and Cambodia, five times in Ghana, two times in Uganda, 1.5 times in Lesotho that of the prevalence among adults in the household survey.

- Scenario C: The proportion of adults (15-49) in the nonhousehold population is $75.00 \%$; and the HIV prevalence among the non-household adults is 20 times in India and Cambodia, 10 times in Ghana, four times in Uganda, two times in Lesotho that of the prevalence among adults in the household survey.

\section{RESULTS}

HIV prevalence among adults (15-49) in the 14 countries ranged from less than $1 \%$ in India and Cambodia to $23.2 \%$ in Lesotho. Despite large HIV prevalence differences among the surveys, fairly consistent patterns of HIV infection are observed by age, sex and urban/rural residence (data not shown).

\section{Estimates of bias because of non-response}

Household response rates were very high in all surveys (93\% or higher) (table 1). Response rates for the individual interview were also above $90 \%$ in most surveys. Individual interview response rates for females ranged from $90 \%$ in Cote d'Ivoire and Zimbabwe to $98 \%$ in Rwanda. Individual interview response rates for males were lower than for females in all 14 countries, and ranged from a low of $82 \%$ in Zimbabwe to $97 \%$ in Rwanda.

Response rates for HIV testing were lower than those for individual interview in all cases. In seven of the 14 countries, the difference in the response rates for individual interview and for HIV testing was greater than 10 percentage points for both males and females. The highest differences were observed in Malawi, where the response rate for HIV testing was 23 percentage points lower for males and 25 percentage points lower for females than the corresponding response rates for individual interview. On the other hand, Rwanda had the smallest differences between the individual interview and HIV testing response rates of about 2 percentage points for males and 1 percentage point for females.

HIV response rates for males were lowest in Malawi and Zimbabwe (63\%), followed by Lesotho (68\%) and Kenya (70\%). The highest male HIV response rates were in Rwanda (96\%), followed by Cambodia and Cameroon ( $90 \%$ each). Similar to individual interview response rates, HIV response rates for females were considerably higher than for males in all countries. Female HIV response rates ranged from $70 \%$ in Malawi to $97 \%$ 
Table 1 Response rates for household interview, individual interview and HIV testing by sex, and reason for HIV non-response, DHS/AIS countries with HIV testing, 2003-6

\begin{tabular}{|c|c|c|c|c|c|c|c|}
\hline \multirow[b]{2}{*}{ Country, sex (age) } & \multirow[b]{2}{*}{$\begin{array}{l}\text { Household } \\
\text { response rate }\end{array}$} & \multirow{2}{*}{$\begin{array}{l}\text { Number eligible for } \\
\text { individual interview and HIV } \\
\text { testing }\end{array}$} & \multirow[b]{2}{*}{$\begin{array}{l}\text { Individual } \\
\text { response rate }\end{array}$} & \multirow[b]{2}{*}{$\begin{array}{l}\text { HIV response } \\
\text { rate }\end{array}$} & \multicolumn{3}{|c|}{ Reason for HIV non-response } \\
\hline & & & & & Refused & Absent & $\begin{array}{l}\text { Other/ } \\
\text { missing }\end{array}$ \\
\hline Burkina Faso 2003 & 99.4 & & & & & & \\
\hline Female (15-49) & & 4575 & 96.7 & 92.3 & 4.0 & 2.0 & 1.7 \\
\hline Cambodia 2005 & 98.0 & & & & & & \\
\hline Male (15-49) & & 7229 & 93.1 & 90.3 & 3.7 & 5.1 & 0.9 \\
\hline Male (15-59) & & 5676 & 93.0 & 89.8 & 5.2 & 3.5 & 1.5 \\
\hline Female (15-49) & & 5703 & 94.5 & 92.1 & 5.1 & 1.5 & 1.3 \\
\hline Cote d'Ivoire 2005 & 95.5 & & & & & & \\
\hline Male (15-49) & & 5148 & 87.5 & 75.8 & 13.9 & 9.2 & 1.1 \\
\hline Female (15-49) & & 5772 & 89.8 & 78.7 & 14.5 & 5.2 & 1.6 \\
\hline Male (15-59) & & 5345 & 93.8 & 80.0 & 10.3 & 7.5 & 2.2 \\
\hline Female (15-49) & & 5949 & 95.7 & 89.3 & 5.3 & 3.7 & 1.8 \\
\hline India 2005-6 & 92.9 & & & & & & \\
\hline Male (15-54) & & 64175 & 86.5 & 78.1 & 6.9 & 12.1 & 3.0 \\
\hline Female (15-49) & & 62182 & 93.6 & 85.0 & 8.1 & 4.5 & 2.4 \\
\hline Kenya 2003 & 96.3 & & & & & & \\
\hline Male (15-54) & & 4183 & 85.5 & 70.3 & 12.8 & 13.9 & 2.9 \\
\hline Female (15-49) & & 4303 & 94.0 & 76.3 & 14.5 & 6.3 & 2.8 \\
\hline Lesotho 2004 & 97.4 & & & & & & \\
\hline Male (15-59) & & 3305 & 84.6 & 68.0 & 16.6 & 8.7 & 6.8 \\
\hline Female (15-49) & & 3758 & 94.2 & 80.7 & 12.1 & 2.9 & 4.3 \\
\hline Malawi 2004 & 97.8 & & & & & & \\
\hline Uganda 2004-5 & 96.8 & & & & & & \\
\hline Male (15-59) & & 9905 & 89.1 & 83.8 & 5.8 & 8.8 & 1.6 \\
\hline Female (15-59) & & 11454 & 94.5 & 89.3 & 5.2 & 4.0 & 1.6 \\
\hline Zimbabwe 2005-6 & 95.0 & & & & & & \\
\hline Male (15-54) & & 8761 & 81.9 & 63.4 & 21.0 & 12.9 & 2.7 \\
\hline Female (15-49) & & 9870 & 90.2 & 75.9 & 15.3 & 6.4 & 2.3 \\
\hline
\end{tabular}

in Rwanda, and were above $90 \%$ also in Cameroon, Burkina Faso and Cambodia.

Refusal was a more important reason for HIV non-response than absence in all countries for women (except in Rwanda) and in nine of the 14 countries for men. In Rwanda, very few women or men refused testing. In all countries, men were much more likely than women to be absent for testing. In 12 of the 14 countries, the HIV non-response rate because of absence was two to four times greater for men than for women.

Non-response rates because of both refusal and absence were much higher in urban areas than in rural areas. Also, the nonresponse rates were considerably higher among more educated and wealthier respondents. In five of the eight countries, where data on chronically ill adults (seriously ill for three or more months in the past year) were available, response rates were slightly higher among chronically ill adults than among adults who were not chronically ill. There were no clear patterns in the HIV non-response rates by various risk and protective factors (data not shown).

In most countries, non-tested males and females have higher predicted HIV prevalence than the observed prevalence among those who were tested (table 2). In eight of the 14 countries for males and in seven of the 14 countries for females, the predicted prevalence among non-tested individuals is significantly greater than the observed prevalence among those tested. In Uganda for both males and females and in Kenya for females, the predicted prevalence among the non-tested individuals is significantly lower than among those tested.

Adjusting the observed national HIV estimates from tested males and females by accounting for the predicted rates among the non-tested makes little difference to the observed estimates in most cases (fig 1). Even in countries where predicted 
Table 2 Predicted HIV prevalence among the non-respondents and adjusted HIV prevalence estimate for all eligible males and females, DHS/AIS countries with linked HIV testing data, 2003-6

\begin{tabular}{|c|c|c|c|c|c|c|c|c|}
\hline \multirow[b]{3}{*}{ Country } & \multirow{3}{*}{$\begin{array}{l}\text { Observed HIV } \\
\text { prevalence } \\
\text { among tested } \\
\text { respondents }\end{array}$} & \multicolumn{6}{|c|}{ Predicted HIV prevalence among non-tested respondents } & \multirow{3}{*}{$\begin{array}{l}\text { Adjusted } \\
\text { prevalence } \\
\text { among all } \\
\text { eligible } \\
\text { respondents }\end{array}$} \\
\hline & & \multicolumn{2}{|c|}{ Interview status } & \multicolumn{3}{|c|}{ Reason not tested } & \multirow[b]{2}{*}{ Total non-tested } & \\
\hline & & Interviewed & Not interviewed & Refused & Absent & $\begin{array}{l}\text { Other/ } \\
\text { missing }\end{array}$ & & \\
\hline \multicolumn{9}{|c|}{ Burkina Faso 2003} \\
\hline Male (15-59) & 1.94 & 2.68 & 2.48 & 2.91 & 2.52 & 2.11 & $2.57^{*}$ & 2.02 \\
\hline Female (15-49) & 1.83 & 3.56 & 2.30 & 3.71 & 2.35 & 2.78 & $3.15^{*}$ & 1.94 \\
\hline Female (15-49) & 0.61 & 1.49 & 0.61 & 1.41 & 0.54 & 0.53 & 1.02 & 0.63 \\
\hline \multicolumn{9}{|l|}{ Cameroon 2004} \\
\hline Male (15-59) & 3.91 & 5.17 & 5.10 & 5.44 & 5.00 & 3.71 & $5.13^{*}$ & 4.04 \\
\hline Female (15-49) & 6.75 & 8.73 & 8.24 & 8.72 & 8.87 & 7.12 & $8.51^{*}$ & 6.90 \\
\hline \multicolumn{9}{|c|}{ Cote d'Ivoire 2005} \\
\hline Male (15-49) & 2.86 & 3.39 & 3.21 & 3.22 & 3.48 & 2.29 & 3.29 & 2.98 \\
\hline \multicolumn{9}{|l|}{ Ghana 2003} \\
\hline Male (15-59) & 1.66 & 2.14 & 1.62 & 2.27 & 1.50 & 2.40 & 1.98 & 1.72 \\
\hline Female (15-49) & 2.70 & 2.97 & 2.46 & 3.10 & 2.40 & 2.56 & 2.77 & 2.70 \\
\hline \multicolumn{9}{|l|}{ India 2005-6 } \\
\hline Male (15-54) & 0.35 & 0.44 & 0.53 & 0.44 & 0.51 & 0.58 & $0.50^{*}$ & 0.38 \\
\hline Female (15-49) & 0.22 & 0.25 & 0.32 & 0.24 & 0.30 & 0.36 & $0.28^{*}$ & 0.23 \\
\hline \multicolumn{9}{|l|}{ Kenya 2003} \\
\hline Male (15-54) & 4.71 & 4.47 & 5.81 & 4.83 & 5.54 & 4.28 & 5.11 & 4.81 \\
\hline Female (15-49) & 8.70 & 6.82 & 9.24 & 7.19 & 8.00 & 7.59 & $7.46^{*}$ & 8.45 \\
\hline \multicolumn{9}{|l|}{ Lesotho 2004} \\
\hline Male (15-59) & 18.94 & 19.12 & 19.18 & 18.94 & 18.32 & 20.66 & 19.15 & 19.01 \\
\hline Female (15-49) & 26.37 & 25.17 & 24.54 & 25.70 & 23.80 & 23.72 & 25.00 & 26.09 \\
\hline \multicolumn{9}{|l|}{ Uganda 2004-5 } \\
\hline Female (15-59) & 7.29 & 6.24 & 7.01 & 6.58 & 6.86 & 5.92 & $6.58^{*}$ & 7.22 \\
\hline \multicolumn{9}{|l|}{ Tanzania 2003} \\
\hline Male (15-49) & 6.26 & 6.84 & 7.38 & 6.99 & 7.37 & 5.45 & $7.04^{*}$ & 6.44 \\
\hline Female (15-49) & 7.70 & 8.40 & 7.20 & 8.36 & 7.29 & 6.94 & 8.11 & 7.77 \\
\hline \multicolumn{9}{|c|}{ Zimbabwe 2005-6 } \\
\hline Male (15-54) & 14.75 & 15.28 & 17.38 & 15.79 & 16.67 & 19.05 & $16.35^{*}$ & 15.28 \\
\hline Female (15-49) & 21.12 & 19.90 & 21.38 & 20.06 & 21.48 & 20.71 & 20.51 & 20.97 \\
\hline
\end{tabular}

\footnotetext{
* Significantly different from the observed prevalence at $\mathrm{p}<0.05$
}

Variables for predicting HIV prevalence in the "not interviewed, not tested" group included age, education, wealth index, residence and geographic region.

Additional variables for predicting HIV in the "interviewed, not tested" group included: marital status; childbirth in last five years (women only); work status; media exposure; ethnicity; religion; circumcision (men only); STI or STI symptoms in the last 12 months; alcohol use at last sex in the last 12 months; number of sex partners in the last 12 months; cigarette smoking/tobacco use; age at first sex; number of lifetime sexual partners; number of sexual partners in the last 12 months; condom use at last sex in the last 12 months; higher-risk sex (sex with a non-marital, non-cohabiting partner) in the last 12 months; knowledge of prevention methods (abstinence, being faithful and condom use); attitudes towards people living with HIV (PLHIV). Woman's ability to negotiate safer sex with spouse; woman's participation in household decision-making (women only); number of medical injections in the last 12 months; duration of stay in current place of residence; number of times slept away in the last 12 months (men only); away (from usual place of residence) for more than one month in the last 12 months (men only); and previously tested for HIV. The list of additional variables used varied slightly from country to country, depending on the availability of information.

prevalence among the non-responders is significantly higher or lower, the adjusted prevalence for all eligible respondents is about the same as the observed prevalence based only on the tested respondents. Although not statistically significant in all 14 countries, the effects of non-response tend to be somewhat greater among lower prevalence countries for both males and females.

\section{Estimates of bias because of exclusion of non-household population}

Our simulation analyses for India, Cambodia, Ghana, Uganda and Lesotho show that under varying assumptions of much greater HIV prevalence among non-household adults, estimated bias because of exclusion of non-household population groups in 
Figure 1 Ratios of adjusted HIV prevalence among all eligible individuals to observed HIV prevalence among those tested in the surveys
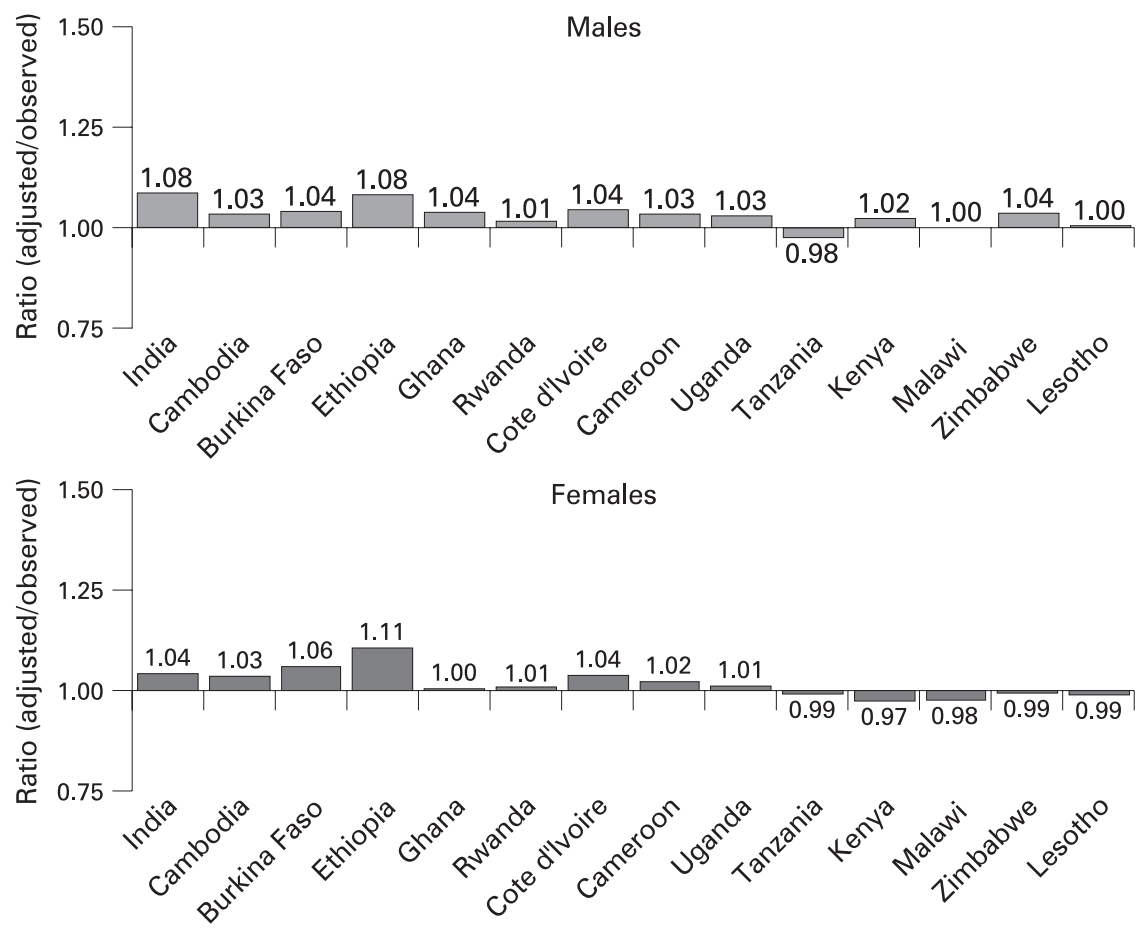

national HIV prevalence estimates from household samples tends to be small (table 3).

In India, for example, under scenario B where the proportion of adults age 15-49 in the non-household population is assumed to be $67 \%$ and the HIV prevalence among non-household adults is assumed to be 10 times the prevalence among household adults $(2.80 \%)$, the estimated HIV prevalence among all adults increases only slightly, from $0.28 \%$ to $0.31 \%$. Under scenario C, where the proportion of adults in the non-household population is assumed to be $75 \%$ and the HIV prevalence among nonhousehold adults is assumed to be 20 times the prevalence among household adults (5.60\%), the estimated HIV prevalence among all adults increases to $0.35 \%$. Similarly, in Cambodia, the observed HIV prevalence in the survey $(0.62 \%)$ increases to $0.77 \%$ under scenario B and $0.98 \%$ under scenario C. In Ghana, Uganda and Lesotho, with much higher levels of HIV prevalence, estimated bias because of exclusion of non-household population groups tends to be relatively smaller.

\section{DISCUSSION}

HIV response rates for females were considerably higher than for males in all countries. The lower response rates for males mainly reflect more frequent absence of men from the households. In 12 of the 14 countries, the HIV non-response rate because of absence was two to four times greater for males than for females. Non-response rates were higher among urban, more-educated and wealthier respondents. These patterns of non-response are typical of most household surveys in developing countries. However, there were no clear patterns in nonresponse rates by various risk and protective factors. Chronically ill adults were equally or more likely to participate in the surveys, suggesting that differential participation of chronically ill adults is unlikely to be a major source of bias.

The non-responder males and females tend to have higher predicted HIV prevalence than those tested. In eight of the 14 countries for males and in seven of the 14 countries for females, non-responders have significantly higher predicted prevalence, but consistent with previous research, the overall effects of nonresponse on the observed national HIV prevalence estimates are small and insignificant in all 14 countries. ${ }^{4}{ }^{17-19}$ The small effects of the non-response bias on the observed national estimates are due mainly to a much smaller proportion of non-responders than those who were tested in the surveys. The effects of nonresponse are somewhat greater among lower prevalence countries for both males and females.

Our analysis of potential bias in the national HIV prevalence estimates because of the exclusion of non-household population in five countries indicated that exclusion of non-household population groups in the surveys is likely to have only a minimal effect on the observed national HIV prevalence estimates. This bias is expected to be greater in countries with concentrated epidemics. Our analysis shows that even in countries with concentrated epidemics (for example, India with a survey HIV prevalence estimate of $0.28 \%$ ), HIV prevalence in the non-household groups needs to be orders of magnitude higher for it to have any significant effect on the national estimate based on the household sample.

In the analysis of the non-response bias, a major limitation is that the estimates are only adjusted to the extent that the sociodemographic and behavioural characteristics included in the analysis are correlated with the risk of HIV infection. Despite including about 30 predictor variables in the regression models, only about $20 \%$ of variation in HIV prevalence is explained in most countries, indicating the limitation of such modelling in explaining behavioural health outcomes. Another limitation is that the adjustments for not interviewed, not tested respondents are based on limited information available from the household questionnaire. Future surveys should attempt to collect additional information on this group (mostly absentees) to better assess potential bias due to their exclusion.

Our analysis is based on de facto household-based sample of the national population. A de facto sample assumes that usual residents (de jure household members) who did not spend the previous night in their own household are, on average, 
Table 3 Potential effects of exclusion of non-household population on the national HIV estimate for adults age 15-49, India, Cambodia, Ghana, Uganda, Lesotho

\begin{tabular}{|c|c|c|c|c|c|c|c|}
\hline & $\begin{array}{l}\text { Projected population in } \\
\text { survey year }\end{array}$ & $\begin{array}{l}\text { \% population } \\
(15-49)\end{array}$ & $\begin{array}{l}\text { Projected population } \\
(15-49)\end{array}$ & HIV prevalence & & $\begin{array}{l}\text { No of HIV+ in } \\
\text { population (15-49) }\end{array}$ & $\begin{array}{l}\text { Estimated HIV } \\
\text { prevalence }\end{array}$ \\
\hline \multicolumn{8}{|l|}{ India 2005-6 } \\
\hline \multicolumn{8}{|c|}{ Scenario A (baseline) } \\
\hline $\begin{array}{l}\text { Population living } \\
\text { in households }\end{array}$ & 1101648431 & $53.18 \%$ & 585804092 & Svy Est & $0.28 \%$ & 1640251 & \\
\hline $\begin{array}{l}\text { Non-household } \\
\text { population }\end{array}$ & 10538569 & $53.18 \%$ & 5603908 & $\mathrm{NHH} \%=\mathrm{Svy} \%$ & $0.28 \%$ & 15691 & \\
\hline Total population & 1112187000 & $53.18 \%$ & 591408000 & & & 1655942 & $0.28 \%$ \\
\hline \multicolumn{8}{|l|}{ Scenario B } \\
\hline $\begin{array}{l}\text { Population living } \\
\text { in households }\end{array}$ & 1101648431 & $53.05 \%$ & 584381936 & Svy Est & $0.28 \%$ & 1636269 & \\
\hline $\begin{array}{l}\text { Non-household } \\
\text { population }\end{array}$ & 10538569 & $66.67 \%$ & 7026064 & $\begin{array}{l}\mathrm{NHH} \%= \\
10^{*} \text { Svy\% }\end{array}$ & $2.80 \%$ & 196730 & \\
\hline \multicolumn{7}{|l|}{ Scenario C } & $0.31 \%$ \\
\hline $\begin{array}{l}\text { Population living } \\
\text { in households }\end{array}$ & 1101648431 & $52.97 \%$ & 583504073 & Svy Est & $0.28 \%$ & 1633811 & \\
\hline $\begin{array}{l}\text { Non-household } \\
\text { population }\end{array}$ & 10538569 & $75.00 \%$ & 7903927 & $\begin{array}{l}\mathrm{NHH} \%= \\
20 * \text { Svy\% }\end{array}$ & $5.60 \%$ & 442620 & \\
\hline Total population & 1112187000 & $53.18 \%$ & 591408000 & & & 2076431 & $0.35 \%$ \\
\hline \multicolumn{8}{|l|}{ Cambodia 2005} \\
\hline \multicolumn{8}{|c|}{ Scenario A (baseline) } \\
\hline $\begin{array}{l}\text { Population living } \\
\text { in households }\end{array}$ & 13056114 & $50.40 \%$ & 6580282 & Svy Est & $0.62 \%$ & 40798 & \\
\hline $\begin{array}{l}\text { Non-household } \\
\text { population }\end{array}$ & 271833 & $50.40 \%$ & 137004 & $\mathrm{NHH} \%=\mathrm{Svy} \%$ & $0.62 \%$ & 849 & \\
\hline Total population & 13327947 & $50.40 \%$ & 6717285 & & & 41647 & $0.62 \%$ \\
\hline \multicolumn{8}{|l|}{ Scenario B } \\
\hline $\begin{array}{l}\text { Population living } \\
\text { in households }\end{array}$ & 13056114 & $50.06 \%$ & 6536054 & Svy Est & $0.62 \%$ & 40524 & \\
\hline $\begin{array}{l}\text { Non-household } \\
\text { population }\end{array}$ & 271833 & $66.67 \%$ & 181231 & $\begin{array}{l}\mathrm{NHH} \%= \\
10^{*} \text { Svy\% }\end{array}$ & $6.20 \%$ & 11236 & \\
\hline Total population & 13327947 & $50.40 \%$ & 6717285 & & & 51760 & $0.77 \%$ \\
\hline \multicolumn{8}{|l|}{ Scenario C } \\
\hline $\begin{array}{l}\text { Population living } \\
\text { in households }\end{array}$ & 13056114 & $49.89 \%$ & 6513411 & Svy Est & $0.62 \%$ & 40383 & \\
\hline $\begin{array}{l}\text { Non-household } \\
\text { population }\end{array}$ & 271833 & $75.00 \%$ & 203875 & $\begin{array}{l}\mathrm{NHH} \%= \\
20 * \text { Svy\% }\end{array}$ & $12.40 \%$ & 25280 & \\
\hline Total population & 13327947 & $50.40 \%$ & 6717285 & & & 65664 & $0.98 \%$ \\
\hline \multicolumn{8}{|l|}{ Ghana 2003} \\
\hline \multicolumn{8}{|c|}{ Scenario A (baseline) } \\
\hline $\begin{array}{l}\text { Population living } \\
\text { in households }\end{array}$ & 18382204 & $48.60 \%$ & 8933751 & Svy Est & $2.16 \%$ & 192969 & \\
\hline $\begin{array}{l}\text { Non-household } \\
\text { population }\end{array}$ & 19982 & $48.60 \%$ & 9711 & $\mathrm{NHH} \%=\mathrm{Svy} \%$ & $2.16 \%$ & 210 & \\
\hline Total population & 18402186 & $48.60 \%$ & 8943462 & & & 193179 & $2.16 \%$ \\
\hline \multicolumn{8}{|l|}{ Scenario B } \\
\hline $\begin{array}{l}\text { Population living } \\
\text { in households }\end{array}$ & 18382204 & $48.58 \%$ & 8930140 & Svy Est & $2.16 \%$ & 192891 & \\
\hline $\begin{array}{l}\text { Non-household } \\
\text { population }\end{array}$ & 19982 & $66.67 \%$ & 13322 & $\begin{array}{l}\mathrm{NHH} \%= \\
5^{*} \text { Svy } \%\end{array}$ & $10.80 \%$ & 1439 & \\
\hline Total population & 18402186 & $48.60 \%$ & 8943462 & & & 194330 & $2.17 \%$ \\
\hline \multicolumn{8}{|l|}{ Scenario C } \\
\hline $\begin{array}{l}\text { Population living } \\
\text { in households }\end{array}$ & 18382204 & $48.57 \%$ & 8928476 & Svy Est & $2.16 \%$ & 192855 & \\
\hline $\begin{array}{l}\text { Non-household } \\
\text { population }\end{array}$ & 19982 & $75.00 \%$ & 14987 & $\begin{array}{l}\mathrm{NHH} \%= \\
10^{*} \text { Svy } \%\end{array}$ & $21.60 \%$ & 3237 & \\
\hline Total population & 18402186 & $48.60 \%$ & 8943462 & & & 196092 & $2.19 \%$ \\
\hline \multicolumn{8}{|l|}{ Uganda 2004-5 } \\
\hline \multicolumn{8}{|c|}{ Scenario A (baseline) } \\
\hline $\begin{array}{l}\text { Population living } \\
\text { in households }\end{array}$ & 26172937 & $42.30 \%$ & 11071153 & Svy Est & $6.38 \%$ & 706340 & \\
\hline $\begin{array}{l}\text { Non-household } \\
\text { population }\end{array}$ & 423793 & $42.30 \%$ & 179264 & $\mathrm{NHH} \%=\mathrm{Svy} \%$ & $6.38 \%$ & 11437 & \\
\hline Total population & 26596730 & $42.30 \%$ & 11250417 & & & 717777 & $6.38 \%$ \\
\hline
\end{tabular}


Table 3 Continued

\begin{tabular}{|c|c|c|c|c|c|c|c|}
\hline & $\begin{array}{l}\text { Projected population in } \\
\text { survey year }\end{array}$ & $\begin{array}{l}\text { \% population } \\
(15-49)\end{array}$ & $\begin{array}{l}\text { Projected population } \\
\text { (15-49) }\end{array}$ & HIV prevalence & & $\begin{array}{l}\text { No of HIV+ in } \\
\text { population (15-49) }\end{array}$ & $\begin{array}{l}\text { Estimated HIV } \\
\text { prevalence }\end{array}$ \\
\hline $\begin{array}{l}\text { Population living } \\
\text { in households }\end{array}$ & 26172937 & $41.91 \%$ & 10967874 & Svy Est & $6.38 \%$ & 699750 & \\
\hline $\begin{array}{l}\text { Non-household } \\
\text { population }\end{array}$ & 423793 & $66.67 \%$ & 282542 & $\begin{array}{l}\mathrm{NHH} \%= \\
2 * \text { Svy\% }\end{array}$ & $12.76 \%$ & 36052 & \\
\hline Total population & 26596730 & $42.30 \%$ & 11250417 & & & 735803 & $6.54 \%$ \\
\hline $\begin{array}{l}\text { Non-household } \\
\text { population }\end{array}$ & 423793 & $75.00 \%$ & 317844 & $\begin{array}{l}\mathrm{NHH} \%= \\
4^{*} \text { Svy } \%\end{array}$ & $25.52 \%$ & 81114 & \\
\hline Total population & 26596730 & $42.30 \%$ & 11250417 & & & 778612 & $6.92 \%$ \\
\hline \multicolumn{8}{|l|}{ Lesotho 2004} \\
\hline \multicolumn{8}{|c|}{ Scenario A (baseline) } \\
\hline $\begin{array}{l}\text { Population living } \\
\text { in households }\end{array}$ & 1866354 & $50.90 \%$ & 949974 & Svy Est & $23.20 \%$ & 220394 & \\
\hline \multicolumn{8}{|l|}{ Scenario B } \\
\hline $\begin{array}{l}\text { Population living } \\
\text { in households }\end{array}$ & 1866354 & $50.83 \%$ & 948726 & Svy Est & $23.20 \%$ & 220104 & \\
\hline $\begin{array}{l}\text { Non-household } \\
\text { population }\end{array}$ & 7913 & $66.67 \%$ & 5276 & $\begin{array}{l}\mathrm{NHH} \%= \\
1.5^{*} \text { Svy\% }\end{array}$ & $34.80 \%$ & 1836 & \\
\hline Total population & 1874267 & $50.90 \%$ & 954002 & & & 221940 & $23.26 \%$ \\
\hline \multicolumn{8}{|l|}{ Scenario C } \\
\hline $\begin{array}{l}\text { Population living } \\
\text { in households }\end{array}$ & 1866354 & $50.80 \%$ & 948067 & Svy Est & $23.20 \%$ & 219952 & \\
\hline $\begin{array}{l}\text { Non-household } \\
\text { population }\end{array}$ & 7913 & $75.00 \%$ & 5935 & $\begin{array}{l}\mathrm{NHH} \%= \\
2 * \text { Svy\% }\end{array}$ & $46.40 \%$ & 2754 & \\
\hline Total population & 1874267 & $50.90 \%$ & 954002 & & & 222705 & $23.34 \%$ \\
\hline
\end{tabular}

\footnotetext{
NHH: non-household; Svy: survey; Est: estimate.
}

Census data on the size of total population, size of non-household population and proportion of adults in the national population were obtained from India 2001 Census, Cambodia 2004 Inter-Censal Survey, Ghana 2000 Census, Uganda 2002 Census, Lesotho 2006 Census.

In India, the actual proportion of non-household adults in the census was $56.15 \%$, much lower than $66.67 \%$ and $75.00 \%$ assumed in scenarios B and C.

In Ghana, the estimate of non-household population refers to homeless population only.

In Lesotho, the estimate of non-household population refers to institutional population only.

interviewed in a household they may be visiting. A de facto sample maximises participation rates and avoids potential double counting of respondents. HIV seroprevalence estimates based on de facto samples may be biased to the extent some of the de jure household members who slept away may not be visiting another household and to the extent such people have differential HIV prevalence.

Furthermore, the adjustments for bias because of nonresponse and exclusion of non-household population groups do not account for a small proportion (usually 1-3\%) of sampled households that were not interviewed in the surveys. Finally, the assumptions regarding HIV prevalence and the proportion

\section{Key messages}

- Non-response in national household surveys tends to have small, not significant effects on HIV seroprevalence estimates based on tested respondents.

- Exclusion of institutional and homeless population in the surveys is likely to have only a minimal effect on national HIV seroprevalence estimates from household surveys.

- Population-based surveys provide reliable, nationally representative direct estimates of HIV seroprevalence in countries with generalised epidemics. of adults in the non-household population are arbitrary. However, in India where information on the age structure of non-household population was available from the census, the proportion of adults (15-49) in the non-household population was much lower (56\%) than the assumed levels of $67 \%$ and $75 \%$ in the analysis. Moreover, because males tend to have lower prevalence than females and because a great majority of the institutional and homeless population tends to be males, our assumptions of 10 and 20 times greater prevalence among nonhousehold adults seems reasonable.

Our analyses suggest that population-based surveys provide reliable, nationally representative direct estimates of HIV seroprevalence in countries with generalised epidemics. HIV prevalence data from population-based surveys can be useful in understanding the magnitude and spread of the epidemics and in calibrating estimates from sentinel surveillance.

Acknowledgements: We acknowledge useful discussions with Martin Vaessen, Ann Way, Anne Cross and Benny Kottiri on the analysis. We thank Yuan Gu for research assistance.

Funding: Funding for this research was provided by the United States Agency for International Development (USAID) and the President's Emergency Plan for AIDS Relief (PEPFAR) through the MEASURE Demographic and Health Surveys project.

Competing interests: All four authors work for Macro International Inc, the agency that helps to conduct demographic and health surveys and AIDS indicator surveys around the world. 
Contributors: VM planned and drafted the paper. RH and SK carried out the analysis and contributed to revising the paper. BB contributed to the conceptualisation of the analysis and revising the paper.

Disclaimer: The views presented in this manuscript are those of the authors and do not necessarily represent the views of the funding agencies or the organisations to which the authors belong.

\section{REFERENCES}

1. WHO and UNAIDS. Guidelines for measuring national HIV prevalence in populationbased surveys. Geneva: WHO and UNAIDS, 2005.

2. Stover J, Ghys PD, Walker N. Testing the accuracy of demographic estimates in countries with generalized epidemics. AIDS 2004;18(Suppl 2):S67-73.

3. http://www.measuredhs.com (accessed 25 April 2008).

4. Mishra V, Vaessen M, Boerma JT, et al. HIV testing in national population-based surveys: experience from the demographic and health surveys. Bull World Health Organ 2006;84:537-45.

5. Walker N, Grassly NC, Garnett GP, et al. Estimating the global burden of HIV/AIDS: what do we really know about the HIV pandemic? Lancet 2004;363:2180-5.

6. García-Calleja JM, Gouws E and Ghys PD. National population based HIV prevalence surveys in sub-Saharan Africa: results and implications for HIV and AIDS estimates. Sex Transm Infect 2006;82(Suppl 3):iii64-70.

7. Boerma JT, Ghys PD, Walker N. Estimates of HIV-1 prevalence from national population-based surveys as a new gold standard. Lancet 2003;362:1929-31.

8. Buve A, Lagarde $E$, Carael $M$, et al. Interpreting sexual behavior data: validity issues in the multicentre study on factors determining the differential spread of HIV in four African cities. AIDS 2001;15(Suppl 4):S117-26.

9. Lydié N, Robinson NJ, Ferry B, et al. Mobility, sexual behavior, and HIV infection in an urban population in Cameroon. J Acquir Immune Defic Syndr 2004;35:67-74.

10. Lagarde $\mathbf{E}$, Schim van der Loeff M, Enel C, et al. Mobility and the spread of human immunodeficiency virus into rural areas of West Africa. Int J Epidemiol 2003;32:74452. Comment in: Int J Epidemiol 2003;32:753-4.

11. Lurie MN, Williams BG, Zuma K, et al. The impact of migration on HIV-1 transmission in South Africa: a study of migrant and nonmigrant men and their partners. Sex Transm Dis 2003;30:149-56.

12. Faisel A, Cleland J. Migrant men: a priority for HIV control in Pakistan? Sex Transm Infect 2006;82:307-10.

13. Zuma K, Lurie MN, Williams BG, et al. Risk factors of sexually transmitted infections among migrant and non-migrant sexual partnerships from rural South Africa. Epidemiol Infect 2005;133:421-8.
14. Nunn AJ, Wagner HU, Kamali A, et al. Migration and HIV-1 seroprevalence in a rural Ugandan population. AIDS 1995;9:503-6.

15. Coffee MP, Garnett GP, Mlilo M, et al. Patterns of movement and risk of HIV infection in rural Zimbabwe. J Infect Dis 2005;191(Suppl 1):S159-67.

16. Martínez-Donate AP, Rangel MG, Hovell MF, et al. HIV infection in mobile populations: the case of Mexican migrants to the United States. Rev Panam Salud Publica 2005;17:26-9.

17. McNaghten AD, Herold JM, Dube HM, et al. Response rates for providing a blood specimen for HIV testing in a population-based survey of young adults in Zimbabwe. BMC Public Health 2007; 7:145

18. Bignami-Van Assche S, Salomon JA, Murray CJL. Evidence from national population-based estimates of bias in HIV prevalence. Presented at Population Association of America Annual Meeting. Philadelphia, 31 March-2 April 2005.

19. Obare F. The effect of non-response on population-based HIV prevalence estimates: the case of rural Malawi. Social Networks Project Working Paper. Philadelphia: University of Pennsylvania, 2005.

20. Dandona R, Dandona L, Gutierrez JP, et al. High risk of HIV in non-brothel based female sex workers in India. BMC Public Health 2005;5:87.

21. Sarkar K, Bal B, Mukherjee R, et al. Epidemiology of HIV infection among brothel-based sex workers in Kolkata, India. J Health Popul Nutr 2005;23:231-5

22. Chimphambano C, Komolafe 00, Muula AS. HIV prevalence among prison inmates in a central prison in southern Malawi, 2005. Trop Doct 2007;37:226-8.

23. Dolan K, Kite B, Black E, et al. HIV in prison in low-income and middle-income countries. Lancet Infect Dis 2007;7:32-41. Comment in: Lancet Infect Dis 2007; 7:1.

24. Wolitski RJ, Kidder DP, Fenton KA. HIV, homelessness, and public health: critical issues and a call for increased action. AIDS Behav 2007;11(Suppl 6):167-71.

25. Macro International. HIV testing field manual: demographic and health surveys. Calverton, MD: Macro International Inc, 2007.

26. Registrar General of India. The census of India 2001. New Delhi: Office of the Registrar General and Census Commission, India, 2001.

27. Royal Government of Cambodia. Cambodia inter-censal population survey 2004 General report. Royal Government of Cambodia, 2005.

28. http://www.ghanainfo.org (accessed 7 February 2008).

29. Uganda Bureau of Statistics. 2002 Uganda population and housing census. Analytical Report Abridged version. Kampala, Uganda: Uganda Bureau of Statistics, 2006.

30. http://www.bos.gov.ls (accessed 7 February 2008). 